\title{
THE HEATS OF COMBUSTION OF METHANE AND CARBON MONOXIDE
}

\author{
By Frederick D. Rossini
}

\section{ABSTRACT}

With the use of the calorimetric apparatus and procedure employed for determining the heat of formation of water (v. supra p. 1), the heats of combustion of methane and carbon monoxide have been measured.

The heat of combustion of $\mathrm{CH}_{4}$ to form liquid $\mathrm{H}_{2} \mathrm{O}$ and gaseous $\mathrm{CO}_{2}$ is found to be $889,700 \pm 300$ international joules per mole at $30^{\circ} \mathrm{C}$. and a constant pressure of 1 atmosphere, which is equivalent to $890,160 \pm 300$ international joules per mole at $25^{\circ} \mathrm{C}$. and $1 \mathrm{~atm}$.

The heat of combustion of $\mathrm{CO}$ to form $\mathrm{CO}_{2}$ is found to be $282,925 \pm 120$ international joules per mole at $30^{\circ} \mathrm{C}$. and a constant pressure of $1 \mathrm{~atm}$., which is equivalent to $282,890 \pm 120$ international joules per mole at $25^{\circ}$ C. and $1 \mathrm{~atm}$.

For comparison with the older work, see Figures 1 and 2.

\section{CONTENTS}

I. Introduction Page

II. Apparatus and calorimetric procedure

III. Molecular weights, constants, units, and factors 38

IV. Methane

1. Chemical procedure 39

2. Correction experiments 41

3. Combustion experiments

4. Data of previous investigators 42

V. Carbon monoxide...... 44

1. Chemical procedure

2. Correction experiments_......... 45

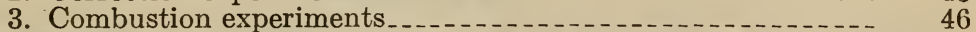

4. Data of previous investigators

VI. Conclusion

VII. Acknowledgment.

\section{INTRODUCTION}

The heats of formation of methane and carbon monoxide are computed from their heats of combustion because of the difficulties inherent in the problem of measuring the heat effect of their synthesis from or decomposition into the elements. Accurate values of the heats of formation of methane and carbon monoxide are particularly desirable at this time because industrial syntheses of many useful compounds involve one or both of these gases, and a knowledge of the heat effect of a given reaction permits calculation of the change of the equilibrium with temperature.

The usually accepted values for the heats of combustion of methane and carbon monoxide are based primarily upon the measurements made over 50 years ago by Thomsen. Because of the comparatively large uncertainty (one-fourth to one-third per cent) attached to Thomsen's average values, and because calorimetric measuring apparatus, methods, and devices have improved greatly in accuracy and precision since his time, it was desirable that new determinations be made. 


\section{APPARATUS AND CALORIMETRIC PROCEDURE}

It was found that the calorimetric apparatus which was used in this laboratory to determine the heat of formation of water ${ }^{1}$ could be used, without alteration, for burning methane and carbon monoxide in oxygen. The reaction vessel and other apparatus have been described in detail. ${ }^{1}$

The calorimetric procedure in the experiments involving combustion of methane and carbon monoxide was exactly similar to that employed in the combustion of hydrogen and the experiments here reported were carried out immediately after the completion of the latter combustions.

The data from the calibration experiments at $30^{\circ}$ C., listed as Set II in the experiments on hydrogen, were used in conjunction with the combustion experiments on methane and carbon monoxide.

While the curves showing the variation of the calorimeter temperature with time in the combustion experiments on hydrogen were practically identical with those in the calibration experiments, those for the combustion experiments involving methane and carbon monoxide were somewhat different. In the calibration experiments, the temperature rise of about $2.8^{\circ} \mathrm{C}$. occurred in 12 minutes, whereas for the combustion experiments on methane and carbon monoxide it was $2.8^{\circ} \mathrm{C}$. in 10 minutes and $1.3^{\circ} \mathrm{C}$. in 12 minutes, respectively. Since, however, detailed observations in the "fore" and "after" periods were made in each experiment, and since the resistance coils in the thermometer bridge were accurately calibrated, the determination of the true temperature rise in each experiment can be in error by only a negligible amount.

\section{MOLECULAR WEIGHTS, CONSTANTS, UNITS, AND FACTORS}

The atomic weights of $\mathrm{O}, \mathrm{H}$, and $\mathrm{C}$ are taken as $16.000,1.0078$, and 12.000 , respectively. ${ }^{2}$

For the reaction between $\mathrm{CH}_{4}$ and $\mathrm{O}_{2}$ to form liquid $\mathrm{H}_{2} \mathrm{O}$ and gaseous $\mathrm{CO}_{2}, \Delta C_{p}$ is taken as 93 joules per mole per degree, ${ }^{3}$ that is, the heat evolved in the reaction at constant pressure decreases 93 joules per mole per degree.

For the reaction between $\mathrm{CO}$ and $\mathrm{O}_{2}$ to form $\mathrm{CO}_{2}, \Delta C_{p}$ is taken as -7 joules per mole per degree. ${ }^{3}$ The heat evolved in this reaction at constant pressure increases 7 joules per mole per degree.

The correction to 1 atmosphere pressure is made by the use of the thermodynamic equation.

$$
w=n \mathbf{R} T \log _{\ominus} \frac{P}{760}
$$

where $n$ is the number of moles decrease in gaseous volume, $\mathbf{R}$ is the gas constant in joules per degree, $T$ is the absolute temperature, $P$ is the pressure in $\mathrm{mm}$ of $\mathrm{Hg}$. For the combustion of methane, $w$ is taken as -6.7 joules per mole per $\mathrm{mm}$ increase in pressure, while for the conbustion of carbon monoxide $w$ is -1.7 joules per mole

1 Rossini, B. S. Jour. Research, 6, p. 1; 1931.

Baxter, 1930 Report of the Committee on Atomic Weights, J. Am. Soc., 52, p. 861; 1930.

International Critical Tables, 5, p. 80. 
per $\mathrm{mm}$ increase in pressure. These corrections are strictly valid only for small changes in pressure. The pressures in the reaction chamber for the combustion experiments are given in Tables 4 and 8 .

The unit of energy and all other constants, units, and factors are the same as those given in the previous paper. ${ }^{4}$

\section{METHANE}

\section{CHEMICAL PROCEDURE}

The methane used in this investigation, obtained through the courtesy of the Fixed Nitrogen Research Laboratory, had been prepared synthetically from carbon monoxide and hydrogen and was specially purified by the Du Pont Ammonia Co. The purifying procedure included a fractional distillation to remove other hydrocarbons, hydrogen, and carbon monoxide.

Before entering the reaction vessel, the methane passed successively through tubes containing (1) "ascarite" (sodium hydroxideasbestos mixture) for removing $\mathrm{CO}_{2}$ and other acidic oxides, (2) "dehydrite" $\left(\mathrm{Mg}\left(\mathrm{ClO}_{4}\right)_{2} .3 \mathrm{H}_{2} \mathrm{O}\right)$ for removing water vapor, and (3) $\mathrm{P}_{2} \mathrm{O}_{5}$ for removing the last traces of $\mathrm{H}_{2} \mathrm{O}$.

The ratio of carbon to hydrogen in the methane was determined by burning the gas in the reaction vessel in an excess of oxygen and absorbing the $\mathrm{H}_{2} \mathrm{O}$ in "dehydrite" and the $\mathrm{CO}_{2}$ in "ascarite." For this absorption, two glass-stoppered U-tubes, similar to that used in the hydrogen combustions, were used in series. The first tube contained "dehydrite" and $\mathrm{P}_{2} \mathrm{O}_{5}$, and the second "ascarite" and $\mathrm{P}_{2} \mathrm{O}_{5}$. The first tube absorbed only the $\mathrm{H}_{2} \mathrm{O}$ while the second absorbed all the $\mathrm{CO}_{2}$. Because of the large amount of heat evolved when "ascarite" absorbs $\mathrm{CO}_{2}$, the second tube was placed in a beaker of water.

The procedure employed in determining the mass of $\mathrm{H}_{2} \mathrm{O}$ formed has been described in detail. ${ }^{5}$

The mass of $\mathrm{CO}_{2}$ absorbed was determined in the same manner. When "ascarite" absorbs $\mathrm{CO}_{2}$, two reactions occur:

$$
2 \mathrm{NaOH} \text { (hydrated) }+\mathrm{CO}_{2}=\underset{\text { hydration) }}{\mathrm{Na}_{2} \mathrm{CO}_{3}} \text { (hydrated) }+\mathrm{H}_{2} \mathrm{O} \text { (water of }
$$

$\mathrm{NaOH}$ (hydrated) $+\mathrm{CO}_{2}=\mathrm{NaHCO}_{3}+\mathrm{H}_{2} \mathrm{O}$ (water of hydration)

The molecular volumes ${ }^{6}$ were taken as follows: $\mathrm{NaHCO}_{3}, 38.2$ $\mathrm{cm}^{3} ; \mathrm{NaOH}$ (hydrated), $18.8 \mathrm{~cm}^{3}+15.6 \mathrm{~cm}^{3}$ for each mole of water of hydration; $\mathrm{Na}_{2} \mathrm{CO}_{3}, 41.8 \mathrm{~cm}^{3}+15.6 \mathrm{~cm}^{3}$ for each mole of water of hydration. The increase in volume of the "ascarite" is $0.45 \pm 0.02$ $\mathrm{cm}^{3}$ per gram of $\mathrm{CO}_{2}$ absorbed. Following a calculation similar to one already described, ${ }^{7}$ the mass of $\mathrm{CO}_{2}$ absorbed becomes, when the absorber is filled with oxygen at $25^{\circ} \mathrm{C}$. and 1 atmosphere.

$$
m_{(\mathrm{CO} 2)}=(1.00000+0.00059-0.00014) \times \Delta m=1.00045 \Delta m
$$

where $m$ is the mass of the brass weights. The uncertainty in this factor is not more than 2 in 100,000 . When the absorber is filled

See footnote 1, p. 38.

See footnote 1, p. 38 .

Calculated from densities and molecular weights given in International Critical Tables, 1, pp. $150,151$.

See footnote 1, p. 38 . 
with hydrogen, as it was in some experiments, the mass of $\mathrm{CO}_{2}$ is obtained from the following equation:

$$
m_{(\mathrm{CO} 2)}=(1.00000+0.00004-0.00014) \times \Delta m=0.99990 \Delta m
$$

The results of four determinations of the ratio of $\mathrm{H}_{2} \mathrm{O}$ to $\mathrm{CO}_{2}$ are given in Table 1. When the methane was burned in oxygen according to the equation

$$
\mathrm{CH}_{4}+2 \mathrm{O}_{2}=2 \mathrm{H}_{2} \mathrm{O}+\mathrm{CO}_{2}
$$

it was found that the ratio of half the moles of $\mathrm{H}_{2} \mathrm{O}$ to the number of moles of $\mathrm{CO}_{2}$ formed was $0.99885 \pm 0.00019$.

\begin{tabular}{|c|c|c|c|c|}
\hline Experiment & Mole of $\mathrm{H}_{2} \mathrm{O}$ & Mole of $\mathrm{CO}_{2}$ & $\begin{array}{l}\text { Ratio: } \\
\frac{1 / 2 \text { moles } \mathrm{H}_{2} \mathrm{O}}{\text { moles } \mathrm{CO}_{2}}\end{array}$ & $\begin{array}{l}\text { Deviation } \\
\text { from mean }\end{array}$ \\
\hline $\begin{array}{l}1 \\
2 \\
3\end{array}$ & \multirow[t]{2}{*}{$\begin{array}{r}0.125614 \\
.111594 \\
.081449 \\
.115400\end{array}$} & \multirow[t]{2}{*}{$\begin{array}{r}0.062886 \\
.055855 \\
.040761 \\
.057783\end{array}$} & $\begin{array}{r}0.99875 \\
.99896 \\
.99911 \\
.99857\end{array}$ & $\begin{array}{r}-0.00010 \\
.00011 \\
.00026 \\
-.00028\end{array}$ \\
\hline Mean & & & .99885 & \pm .00019 \\
\hline
\end{tabular}

TABLE 1.-Ratio of $\mathrm{H}_{2} \mathrm{O}$ to $\mathrm{CO}_{2}$ in the combustion products of methane

The excess of $\mathrm{CO}_{2}$ could be explained by the presence in the methane of a small amount of $\mathrm{CO}$. Accordingly, the methane was analyzed directly for $\mathrm{CO}$ by the gas chemistry section of this bureau with the aid of the $\mathrm{I}_{2} \mathrm{O}_{5}$ apparatus developed by them. ${ }^{8}$ The results of their analyses are given in Table 2. While the ratio of $\mathrm{H}_{2} \mathrm{O}$ to $\mathrm{CO}_{2}$ indicated the presence of $\mathrm{CO}$ to the extent of $(0.115 \pm 0.019)$ per cent, the direct analyses gave $(0.1219 \pm 0.0013)$ per cent. For the purpose of correcting the calorimetric data for the amount of $\mathrm{CO}$ present, this was taken as 0.122 per cent.

\begin{tabular}{|c|c|c|c|c|c|}
\hline Experiment & $\begin{array}{l}\text { Observed } \\
\text { volume of } \\
\mathrm{CH}_{4}\end{array}$ & $\begin{array}{l}\text { Observed } \\
\text { volume of } \\
\mathrm{Na}_{2} \mathrm{O}_{3} \mathrm{O}_{3} \\
\text { solution }\end{array}$ & $\begin{array}{c}\text { Calculated } \\
\text { volume of } \\
\text { CO }\end{array}$ & $\mathrm{CO}$ & $\begin{array}{l}\text { Deviation } \\
\text { from mean }\end{array}$ \\
\hline Mean & $\begin{array}{l}m l \\
486.4 \\
488.0 \\
484.0\end{array}$ & $\begin{array}{l}m l \\
10.80 \\
11.05 \\
10.64\end{array}$ & $\begin{array}{l}m l \\
0.5915 \\
.6050 \\
.5830\end{array}$ & $\begin{array}{r}\text { Per cent } \\
0.1215 \\
.1239 \\
.1204 \\
.1219\end{array}$ & $\begin{array}{r}-0.0004 \\
.0020 \\
-.0015 \\
\pm .0013\end{array}$ \\
\hline
\end{tabular}

TABLE 2.-Determination of $\mathrm{CO}$ in the methane

In the combustion experiments on methane, the amount of reaction was determined from the mass of $\mathrm{H}_{2} \mathrm{O}$ formed.

Since the determination of the ratio of $\mathrm{H}_{2} \mathrm{O}$ to $\mathrm{CO}_{2}$ in the products of combustion of the methane gas showed that, exclusive of the 0.122 per cent of $\mathrm{CO}$, the ratio of the number of $\mathrm{C}$ atoms to one-fourth the number of $\mathrm{H}$ atoms was $1.0000 \pm 0.0002$, the amount of $\mathrm{H}_{2}$ or

${ }^{8}$ (a) This apparatus and method are described by J. H. Eiseman in the Gas Chemists' Hand Book, p. 289; 1929. American Gas Association, New York. (b) Lamb, Bray, and Frazer, Ind. Eng. Chem., 12, ए. $213 ; 1920$. 
$\mathrm{C}_{2} \mathrm{H}_{6}$ which could be present in the methane without being detected was about 0.04 or 0.06 mole per cent, respectively. The amount of any hydrocarbon other than $\mathrm{C}_{2} \mathrm{H}_{6}$ which could have been present is less than 0.06 mole per cent. The following table shows the per cent error in the heat of combustion of methane caused by undetected amounts of these substances:

\begin{tabular}{|c|c|c|}
\hline Impurity & $\begin{array}{l}\text { Possible } \\
\text { undetected } \\
\text { amount }\end{array}$ & $\begin{array}{l}\text { Error in } \\
\text { heat effect } \\
\text { caused by } \\
\text { undetected } \\
\text { amount }\end{array}$ \\
\hline $\begin{array}{l}\mathrm{H}_{2} \\
\mathrm{C}_{2} \mathrm{H}_{6} \\
\mathrm{C}_{2} \mathrm{H}_{4} \\
\mathrm{C}_{2} \mathrm{H}_{2} \\
\mathrm{C}_{3} \mathrm{H}_{8}\end{array}$ & $\begin{array}{c}\text { Mole } \\
\text { per cent } \\
0.04 \\
.06 \\
.02 \\
.007 \\
.03\end{array}$ & $\begin{array}{c}\text { Per cent } \\
0.013 \\
.014 \\
.011 \\
.014 \\
.014\end{array}$ \\
\hline
\end{tabular}

The proper ratio of $\mathrm{C}$ to $\mathrm{H}$ could have been maintained by suitable amounts of hydrogen and other hydrocarbons than methane. The following table shows the amount of such impurities required to produce an error of 0.01 per cent in the heat of combustion of methane.

\begin{tabular}{|c|c|}
\hline Impurity & $\begin{array}{l}\text { Amount of im- } \\
\text { purity required } \\
\text { to produce an } \\
\text { error of 0.01 per } \\
\text { cent in the heat } \\
\text { effect }\end{array}$ \\
\hline & $\begin{array}{c}\text { Mole per cent } \\
0.39 \\
\mathrm{C}_{2} \mathrm{H}_{6}+\mathrm{H}_{2} \\
\mathrm{C}_{2} \mathrm{H}_{4}+2 \mathrm{H}_{3}\end{array}$ \\
$\mathrm{C}_{2} \mathrm{H}_{2}+3 \mathrm{H}_{2}$ & .14 \\
$\mathrm{C}_{3} \mathrm{H}_{8}+2 \mathrm{H}_{2}$ & .094 \\
\hline
\end{tabular}

\section{CORRECTION EXPERIMENTS}

As in the combustion experiments with hydrogen, the calorimetric experiments where methane was burned in oxygen had associated with them in addition to the heat of the given reaction, three sources or sinks of energy which were not present in the calibration experiments: (1) the energy given to the calorimeter by the sparking operation (2) the energy required to bring the inflowing gases to the temperature of the calorimeter, and (3) the energy of vaporization of the $\mathrm{H}_{2} \mathrm{O}$ not condensed to liquid.

The "spark" energy, determined as in the hydrogen experiments, was found to be 1.60 joules per second. The "gas" energy and the "vaporization". energy were calculated as before.

An experiment involving three separate ignitions and extinctions of the methane flame was made to test the validity of the energy corrections. The data obtained in this experiment are given in Table 3. The measured amount of energy was $3,124.3$ international joules, while the calculated sum of the "spark," "gas," and "vaporization" energies, and the energy liberated by the combustion of the $\mathrm{CH}_{4}$, is $3,124.8$ international joules. The difference of 0.5 joule is well within 
the experimental error. The heat effect of the solution of $\mathrm{CO}_{2}$ in the water formed is calculated to be negligible ( 1 or 2 parts per 100,000).

TABLE 3.-Correction experiment for combustion of methane

Electrical equivalent of calorimeter.............-int. joules $/{ }^{\circ} \mathrm{C}$ Corrected temperature rise $E$, the total energy

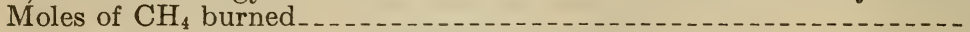
$E_{1}$, "spark" energy $E_{2}$, "gas" energy $E_{3}$, "vaporization" energy $E_{4}$, Heat of combustion of $\mathrm{CH}_{4}(+0.122$ per cent $\mathrm{CO})$ $E_{1}+E_{2}+E_{3}+E_{4} \ldots \ldots$

15632. 6 0.19986 3124. 3 0.035278 28. 8 $-5.2$ $-38.3$ 3139. 5 3124. 8

\section{COMBUSTION EXPERIMENTS}

The experiments on the combustion of methane were performed in the same manner as were the hydrogen combustions. The results are given in Table 4. The result of experiment $\mathrm{A}$ is not included in obtaining the average. The "error" of the mean ${ }^{9}$ is calculated from the equation

$$
\text { "Error" of the mean }= \pm 2 \sqrt{\frac{\sum(\bar{x}-x)^{2}}{n(n-1)}}
$$

when $\Sigma(\bar{x}-x)^{2}$ is the sum of the squares of the deviations of $n$ experiments. The value obtained for the heat of the reaction

$$
\mathrm{CH}_{4 \text { (gas) }}+2 \mathrm{O}_{2 \text { (gas) }}=2 \mathrm{H}_{2} \mathrm{O}_{\text {(1 liquid) }}+\mathrm{CO}_{2 \text { (gas) }}
$$

is $889,700 \pm 270$ international joules per mole at $30^{\circ} \mathrm{C}$. and a constant pressure of 1 atmosphere.

\section{DATA OF PREVIOUS INVESTIGATORS}

The heat of combustion of methane was measured by Andrews ${ }^{10}$ in 1848, Favre and Silbermann ${ }^{11}$ in 1852 , Thomsen ${ }^{12}$ in 1880 , and Berthelot ${ }^{13}$ in 1881 .

\begin{tabular}{|c|c|c|c|c|c|c|c|c|}
\hline Experiment & $\Delta R$ & $k$ & $u$ & $K$ & $U$ & $\Delta R_{\text {corr. }}$ & $\frac{\mathrm{d} R}{\mathrm{~d} \ell}$ & $\Delta t_{\text {oorr. }}$ \\
\hline & $\begin{array}{c}\text { Uhm } \\
0.291604 \\
.291832 \\
.288904 \\
.287126 \\
.293829 \\
.290884\end{array}$ & $\begin{array}{r}\text { Ohm/min/ } \\
\text { ohm } \\
0.001873 \\
1899 \\
1867 \\
1892 \\
1903 \\
1888\end{array}$ & $\begin{array}{r}\text { Ohm/min } \\
-0.0000063 \\
63 \\
37 \\
106 \\
268 \\
58\end{array}$ & $\begin{array}{r}\text { Ohm } \\
0.002721 \\
2552 \\
3468 \\
2722 \\
2725 \\
2619\end{array}$ & $\begin{array}{r}\text { Ohm } \\
-0.000101 \\
101 \\
59 \\
170 \\
429 \\
93\end{array}$ & $\begin{array}{c}\text { Ohm } \\
0.288984 \\
.289179 \\
.285377 \\
.284235 \\
.290675 \\
.288172\end{array}$ & $\begin{array}{r}0 h{ }^{\circ}{ }^{\circ} C . \\
0.100730 \\
30 \\
31 \\
30 \\
30 \\
30\end{array}$ & $\begin{array}{l}\circ C . \\
2.86890 \\
2.87083 \\
2.83306 \\
2.82175 \\
2.88568 \\
2.86084\end{array}$ \\
\hline
\end{tabular}

TABLE 4.-Experiments on combustion of methane

\footnotetext{
- See footnote 1, p. 38.
}

${ }_{10}$ Andrews, Phil. Mag., 32, n. 326; 1848.

11 Favre and Silbermann, Annales chim. phys., 34, p. 426; 1852.

12 Thomsen, (a) Berichte, 13, p. 1323; 1880 . (b) "Thermochemische Untersuchungen," 4, p. 48. J. A. Barth, Leipzig; 1886

13 Berthelot, Annales chim. phys., 28, p. 178; 1881. 
TABLE 4.-Experiments on combustion of methane-Continued

\begin{tabular}{|c|c|c|c|c|c|c|c|c|c|c|c|}
\hline Experiment & $\begin{array}{c}\text { Average } \\
\text { te.npera } \\
\text { ture }\end{array}$ & $\begin{array}{c}\text { Mass of } \\
\text { calorimeter } \\
\text { water }\end{array}$ & $\begin{array}{c}\text { One-half } \\
\text { mass of } \\
\text { liquid } \\
\mathrm{H}_{2} \mathrm{O} \\
\text { formed }\end{array}$ & $\begin{array}{c}\text { Electrical } \\
\text { equivalent } \\
\text { of calorim- } \\
\text { eter system }\end{array}$ & $\begin{array}{l}\text { Pressure } \\
\text { in reac- } \\
\text { tion } \\
\text { chamber }\end{array}$ & \multicolumn{2}{|c|}{$\begin{array}{l}\text { Total } \\
\text { energy }\end{array}$} & & $\begin{array}{l}\text { tas" } \\
\text { ergy }\end{array}$ & \multicolumn{2}{|c|}{$\begin{array}{l}\text { "Vapori- } \\
\text { zation" } \\
\text { energy }\end{array}$} \\
\hline & $\begin{array}{l}{ }^{\circ} C . \\
30.02 \\
30.03 \\
30.01 \\
30.03 \\
30.02 \\
30.02 \\
.\end{array}$ & $\begin{array}{c}g \\
3,687.80 \\
3,692.00 \\
3,686.63 \\
3,684.10 \\
3,674.80 \\
3,689.43\end{array}$ & $\begin{array}{l}g \\
0.86 \\
.90 \\
.88 \\
.88 \\
.89 \\
.88\end{array}$ & $\begin{array}{r}\text { Int. joules/ } \\
\text { C. } \\
15,673.6 \\
15,691.3 \\
15,668.8 \\
15,658.2 \\
15,619.5 \\
15,680.7\end{array}$ & $\begin{array}{r}\mathrm{Hg} \\
762 \\
761 \\
759 \\
753 \\
750 \\
761\end{array}$ & \multicolumn{2}{|c|}{$\begin{array}{r}\text { Int. joules } \\
44,966.0 \\
45,047.1 \\
44,390.7 \\
44,183.5 \\
45,072.9 \\
44,860.0\end{array}$} & & $\begin{array}{r}\text { rules } \\
33.8 \\
9.1 \\
15.5 \\
6.9 \\
11.5 \\
23.8\end{array}$ & \multicolumn{2}{|c|}{$\begin{array}{l}\text { Joules } \\
249.6 \\
168.5 \\
202.5 \\
158.8 \\
155.1 \\
160.7\end{array}$} \\
\hline Experiment & $\begin{array}{l}\text { "Spark" } \\
\text { energy }\end{array}$ & $\begin{array}{l}\text { Reaction } \\
\text { energy }\end{array}$ & $\begin{array}{c}\text { Moles of } \\
\mathrm{CH}_{4}\end{array}$ & $Q_{p, t}$ & $\begin{array}{l}\text { Correc- } \\
\text { tion to } \\
30^{\circ} \mathrm{C} \text {. }\end{array}$ & $\begin{array}{l}\text { Correc- } \\
\text { tion to 1 } \\
\text { atmos- } \\
\text { phere }\end{array}$ & $\begin{array}{l}\text { Corr } \\
\text { tion } \\
0.122 \\
\text { CC }\end{array}$ & \multicolumn{3}{|c|}{$\begin{array}{c}Q_{30^{\circ}} \mathrm{C} . \\
\text { 1 atm. }\end{array}$} & $\begin{array}{l}\text { Devi- } \\
\text { ation } \\
\text { from } \\
\text { mean }\end{array}$ \\
\hline $\begin{array}{l}\text { A } \\
\text { B } \\
\text { C.... } \\
\text { D } \\
\text { E } \\
F_{\ldots}\end{array}$ & $\begin{array}{c}\text { Joules } \\
16 \\
9.6 \\
30.4 \\
9.6 \\
9.6 \\
9.6\end{array}$ & $\begin{array}{r}\text { Int. joules } \\
45,233.4 \\
45,215.1 \\
44,578.3 \\
44,339.6 \\
45,229.9 \\
45,034.9\end{array}$ & $\begin{array}{r}0.0507360 \\
.0507829 \\
.0501019 \\
.0498038 \\
.0508121 \\
.0506131\end{array}$ & $\begin{array}{c}\text { Int. joules/ } \\
\text { mole } \\
891,544 \\
890,361 \\
889,753 \\
890,285 \\
890,141 \\
889,788\end{array}$ & $\begin{array}{l}\text { Joules/ } \\
\text { mole } \\
-2 \\
-3 \\
-1 \\
-3 \\
-2 \\
-2\end{array}$ & $\begin{array}{c}\text { Joules/ } \\
\text { mole } \\
+13 \\
7 \\
-7 \\
-47 \\
-67 \\
7\end{array}$ & $\begin{array}{c}\text { Joul } \\
\text { mol } \\
-3 \\
-3 \\
-3 \\
-3 \\
-3 \\
-3\end{array}$ & \multicolumn{3}{|c|}{$\mid \begin{array}{c}\text { Int. joules/ } \\
\text { mole } \\
(891,210) \\
890,020 \\
889,400 \\
889,890 \\
889,727 \\
889,448\end{array}$} & $\begin{array}{r}323 \\
-297 \\
193 \\
30 \\
-249\end{array}$ \\
\hline Mean. & & & & & & & & & \multicolumn{2}{|c|}{889,700} & \pm 218 \\
\hline
\end{tabular}

Electrical equivalent of calorimeter system with $3,700.00 \mathrm{~g}$ water at $30^{\circ} \mathrm{C} .=15,720.9$ international joules per ${ }^{\circ} \mathrm{C}$.

Because of the large amounts of impurities present in the methane burned by Andrews and by Favre and Silbermann, and because of the fact that lack of suitable calibration of their calorimeter systems makes sufficiently accurate translation of their data into modern energy units practically impossible, their results are not reviewed here.

Thomsen burned methane in a reaction vessel at constant pressure. The amount of reaction was determined from the $\mathrm{CO}_{2}$ formed by absorption in $\mathrm{KOH}$ solution. The results of the 11 experiments reported by Thomsen, corrected to $30^{\circ} \mathrm{C}$. (presumably at 1 atmosphere), and to international joules per mole, are given in Table 5. Computing the "error" of the average by equation (5), the result of Thomsen's data becomes $886,380 \pm 2,840$ international joules per mole. This includes an estimated error of 0.1 per cent in the calibration of his calorimeter; that is, in his calculation of the heat capacity of his calorimeter.

Berthelot reported the results of three experiments in which methane was exploded with oxygen in a bomb at constant volume. The amount of reaction was determined from the mass of methane, computed from its volume, pressure, and temperature. The data of Berthelot, corrected to international joules per mole at $30^{\circ} \mathrm{C}$. and 1 atmosphere, are given in Table 6 . The average of these data is $891,700 \pm 9,000$ international joules per mole. The "error" includes an estimated error of 0.1 per cent in calibration.

The individual values of the experiments by Thomsen and by Berthelot, together with the present data, are shown in Figure 1. The circles or arcs are drawn with radii equal to the assigned 


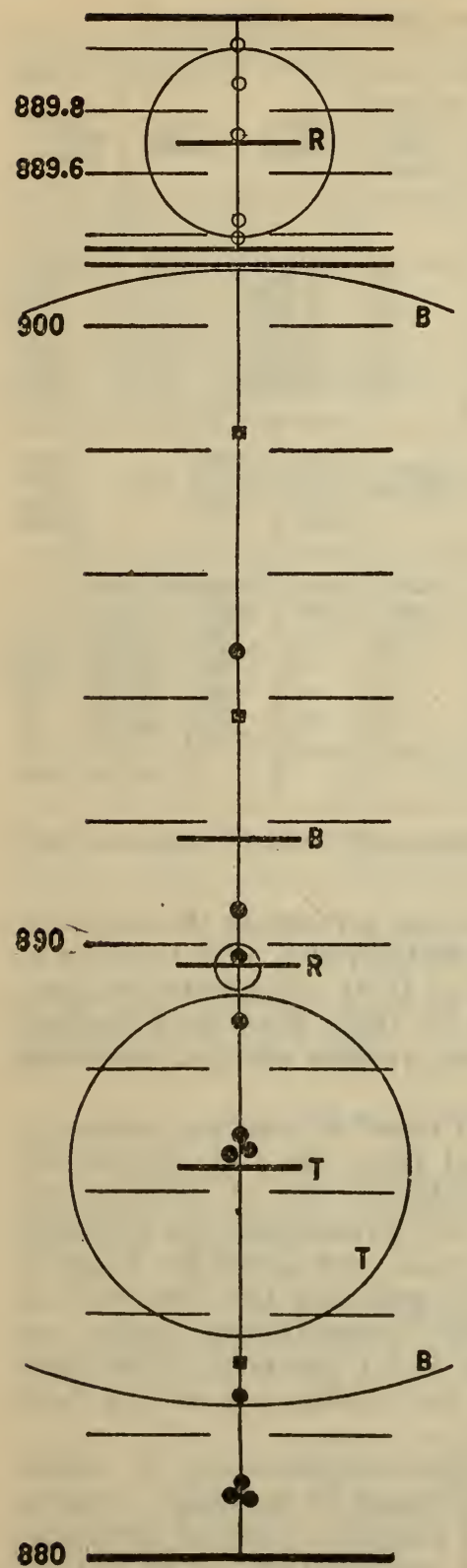

Figore 1.-Plot of the data on the heat of combustion of methane

The ordinate scale gives the heat of com. bustion of mothane in international kilojoules per mole at $30^{\circ} \mathrm{C}$., and 1 atmosphere. The points designate the data of the various investigators: Berthelot; Thom. sen; $O$, Rossini. "errors." The upper section of Figure 1 shows a magnified view of that portion of the lower scale in which fall the values obtained in this investigation.

TABLE 5.-Results obtained by Thomsen on the combustion of methane

\begin{tabular}{|c|c|c|}
\hline Experiment & $Q 80^{\circ} \mathrm{C} ., 1$ stm. & $\begin{array}{l}\text { Deviation } \\
\text { from mean }\end{array}$ \\
\hline $\begin{array}{l}1 \\
4 \\
4 \\
4 \\
4\end{array}$ & $\begin{array}{c}\text { Int. joules per } \\
\text { mole } \\
886,770 \\
888,770 \\
881,020 \\
889,820 \\
886,890 \\
882,660\end{array}$ & $\begin{array}{r}390 \\
2,390 \\
-3,360 \\
3,440 \\
510 \\
3,720\end{array}$ \\
\hline $\begin{array}{l}7 \\
8 \\
9 \\
90 \\
11\end{array}$ & $\begin{array}{l}881,240 \\
886,680 \\
881,080 \\
894,750 \\
890,540\end{array}$ & $\begin{array}{r}-5,140 \\
300 \\
-5,300 \\
8,370 \\
4,170\end{array}$ \\
\hline Mean. & $886,380^{\circ}$ & $\pm 3,550$ \\
\hline
\end{tabular}

TABLE 6.-Results obtained by Berthelot on the combustion of methane

\begin{tabular}{|r|r|r|}
\hline Experiment & $Q_{30}^{\circ} \mathrm{C.}, 1 \mathrm{stm}$. & $\begin{array}{r}\text { Deviation } \\
\text { from mean }\end{array}$ \\
\hline & Int. joules/mole & \\
& 893,700 & 2,000 \\
& 898,300 & 6,600 \\
& 883,200 & $-8,500$ \\
\hline Mean - & 891,700 & $\pm 5,700$ \\
\hline
\end{tabular}

\section{CARBON MONOXIDE}

\section{CHEMICAL PROCEDURE}

The carbon monoxide used in this investigation had been prepared by the Fixed Nitrogen Research Laboratory. ${ }^{14}$ The gas was made by decomposing formic acid with phosphoric acid at $170^{\circ} \mathrm{C}$, according to the reaction.

$$
\mathrm{HCOOH}=\mathrm{CO}+\mathrm{H}_{2} \mathrm{O}
$$

The product was purified from traces of undecomposed acid with sodium hydroxide solution. Scrubbings with potassium hydroxide solution, and passage through a cold trap at $-80^{\circ} \mathrm{C}$., preceded

"Thompson, Ind. Eng. Chem., 21, p. 389; 1829. 
the compression of the gas into steel cylinders. A possible small impurity of hydrogen might arise from the reaction

$$
\mathrm{HCOOH}=\mathrm{CO}_{2}+\mathrm{H}_{2}
$$

Because of its contact with the iron of the steel cylinder in which it was kept, the carbon monoxide contained, besides moisture, a small amount of iron carbonyl whose presence is easily detected by the yellow color it imparts to the flame. This iron carbonyl was decomposed into $\mathrm{Fe}$ and $\mathrm{CO}$ by passage through a tube filled with preignited asbestos at a temperature of about $500^{\circ} \mathrm{C}$.

This process of eliminating the iron carbonyl resulted in the occurrence of two other reactions, as follows:

$$
\begin{gathered}
2 \mathrm{CO}=\mathrm{C}+\mathrm{CO}_{2} \\
\mathrm{H}_{2} \mathrm{O}+\mathrm{CO}=\mathrm{CO}_{2}+\mathrm{H}_{2}
\end{gathered}
$$

The $\mathrm{C}$ was deposited in the asbestos while the $\mathrm{CO}_{2}$ formed, along with that which was originally in the carbon monoxide, was removed by passage through a tube containing "ascarite." The $\mathrm{H}_{2}$ formed in the second reaction between $\mathrm{H}_{2} \mathrm{O}$ and $\mathrm{CO}$, remained in the carbon monoxide. The amount of $\mathrm{H}_{2}$ was determined by absorbing, in separate U-tubes, the $\mathrm{CO}_{2}$ and $\mathrm{H}_{2} \mathrm{O}$ formed, as described in the preceding section under the determination of the ratio of $\mathrm{C}$ to $\mathrm{H}$ in $\mathrm{CH}_{4}$. Two determinations of the amount of $\mathrm{H}_{2}$ in the carbon monoxide entering the reaction vessel gave, respectively, 0.105 and 0.101 mole per cent. This consisted of the $\mathrm{H}_{2}$ formed in the hot tube, together with a small amount (about 0.04 per cent) which was originally in the carbon monoxide.

In determining the amount of $\mathrm{CO}$ burned in the combustion experiments, the mass of $\mathrm{CO}_{2}$ (plus the small amount of $\mathrm{H}_{2} \mathrm{O}$ formed) was obtained, the correction to vacuum being made with the aid of equations (4) and (5). From this mass was subtracted the amount of $\mathrm{H}_{2} \mathrm{O}$ absorbed ( 0.042 weight per cent), and the result divided by 44.000 , the molecular weight of $\mathrm{CO}_{2}$, to give the number of moles of $\mathrm{CO}$ burned. The measured reaction energy was decreased by an amount corresponding to the combustion of the 0.103 mole per cent of $\mathrm{H}_{2}$ to form gaseous $\mathrm{H}_{2} \mathrm{O}$.

\section{CORRECTION EXPERIMENTS}

Pure dry carbon monoxide is difficult to ignite, but the presence of $\mathrm{H}_{2}$ or $\mathrm{H}_{2} \mathrm{O}$ greatly decreases this difficulty. The presence of the 0.1 per cent $\mathrm{H}_{2}$ in the carbon monoxide was advantageous in this regard, but even so, it was found that a much longer time of sparking ( 5 to 30 seconds) was required to ignite the carbon monoxide than was necessary for either the hydrogen or the methane. This accounts for the failure to obtain the expected greater precision in the combustion experiments on carbon monoxide.

The "spark" energy, determined as before, was now found to be 1.28 joules per second. The "gas" energy was calculated as in the previous experiments. In order to check the validity of the "spark" and "gas" energy corrections, three separate experiments were 
performed. The results are given in Table 7 . The difference between the measured energy, $E$, and the computed sum of the energies, $E_{1}+E_{2}+E_{4}$, are with one exception, well within the experimental error.

TABLE 7.-Correction experiments for combustion of carbon monoxide

\begin{tabular}{|c|c|c|c|}
\hline & \multicolumn{3}{|c|}{ Experiment } \\
\hline & 1 & 2 & 3 \\
\hline 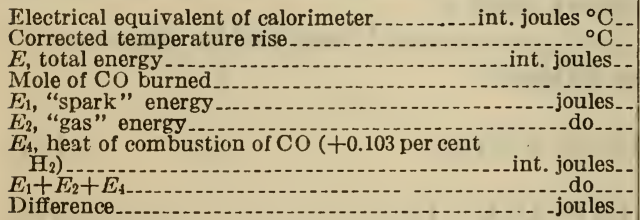 & $\begin{array}{l}15621.3 \\
0.05167 \\
807.1 \\
0.0027020 \\
42.2 \\
-1.5 \\
765.2 \\
805.9 \\
-1.2\end{array}$ & $\begin{array}{l}\text { 15621. } 3 \\
\quad 0.05041 \\
787.5 \\
0.0025221 \\
80.6 \\
-1.5 \\
714.3 \\
793.4 \\
+5.9\end{array}$ & $\begin{array}{l}15621.3 \\
0.03078 \\
480.8 \\
0.0014771 \\
64.0 \\
-1.5 \\
418.3 \\
480.8 \\
0.0\end{array}$ \\
\hline
\end{tabular}

\section{COMBUSTION EXPERIMENTS}

The data of the combustion experiments involving carbon monoxide are given in Table 8 . The electrical equivalent of the calorimeter is 0.9 joule per degree less than in the previous experiments because of the removal of $0.24 \mathrm{~g}$ of copper.

The average of the eight experiments gives for the heat of combustion of $\mathrm{CO}$, according to the equation

$$
\mathrm{CO}_{\text {(gas) }}+1 / 2 \mathrm{O}_{2 \text { (gas) }}=\mathrm{CO}_{2 \text { (gas) }}
$$

$282,925 \pm 100$ international joules per mole at $30^{\circ} \mathrm{C}$. and a constant pressure of $1 \mathrm{~atm}$. The "error" is calculated according to equation (7).

TABLE 8.-Experiments on combustion of carbon monoxide

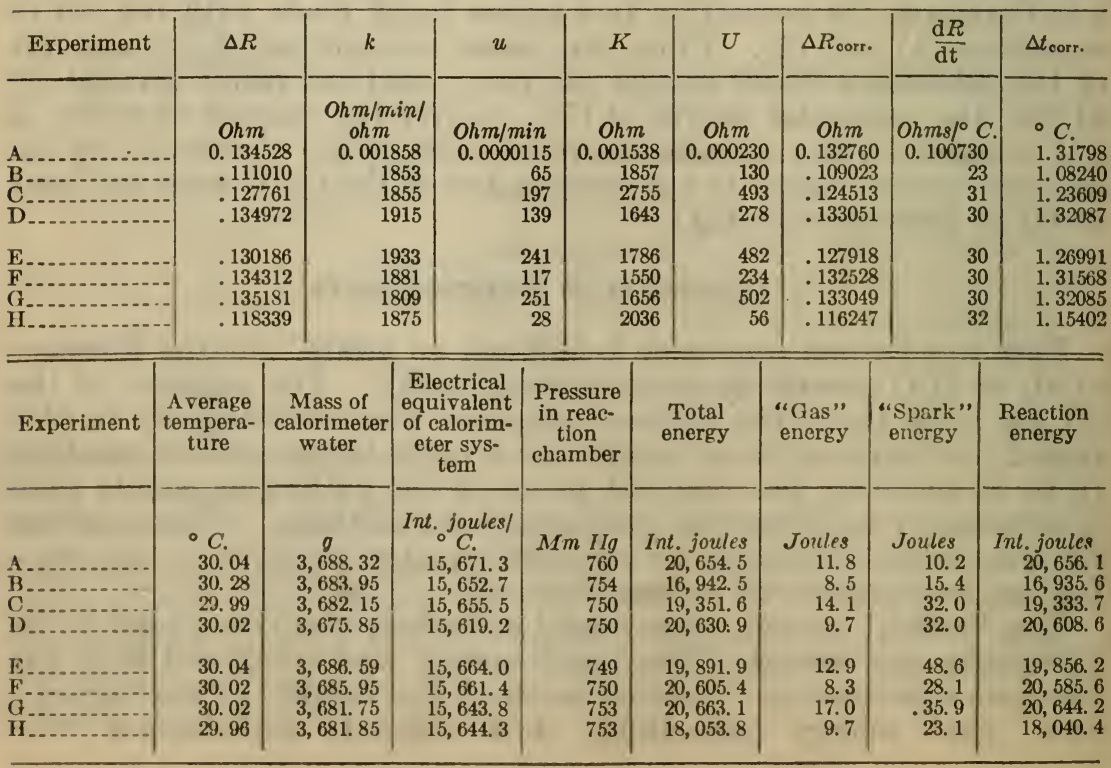


TABLE 8.-Experiments on combustion of carbon monoxide-Continued

\begin{tabular}{|c|c|c|c|c|c|c|c|}
\hline Experiment & $\begin{array}{c}\text { Moles of } \\
\text { CO }\end{array}$ & $Q_{\mathrm{D}, \mathrm{t}}$ & $\begin{array}{l}\text { Correction } \\
\text { to } 30^{\circ} \mathrm{C} \text {. }\end{array}$ & $\begin{array}{l}\text { Correction } \\
\text { to } 1 \text { atmos- } \\
\text { phere }\end{array}$ & $\begin{array}{c}\text { Coriection } \\
\text { for } 0.103 \\
\text { per cent } \mathrm{H}_{2}\end{array}$ & $Q_{30}{ }^{\circ} \mathrm{C} ., 1$ atm. & $\begin{array}{l}\text { Deviation } \\
\text { from mean }\end{array}$ \\
\hline & $\begin{array}{r}0.0729688 \\
.0597962 \\
.0682694 \\
.0728097\end{array}$ & $\begin{array}{r}\text { Int. joules/ } \\
\text { mole } \\
283,077 \\
283,223 \\
198 \\
048\end{array}$ & $\begin{array}{r}\text { Joules/mole } \\
0 \\
-2 \\
0 \\
0\end{array}$ & $\begin{array}{r}\text { Joules/mole } \\
0 \\
-10 \\
-17 \\
-17\end{array}$ & $\begin{array}{r}\text { Joules/mole } \\
-249 \\
-249 \\
-249 \\
-249\end{array}$ & \begin{tabular}{|c} 
Int. joules/ \\
mole \\
282,828 \\
282,962 \\
282,932 \\
282,782
\end{tabular} & $\begin{array}{r}-97 \\
37 \\
7 \\
-143\end{array}$ \\
\hline & $\begin{array}{l}.0700779 \\
.0727235 \\
.0729188 \\
.0636511\end{array}$ & $\begin{array}{l}345 \\
068 \\
113 \\
426\end{array}$ & $\begin{array}{l}0 \\
0 \\
0 \\
0\end{array}$ & $\begin{array}{l}-18 \\
-17 \\
-12 \\
-12\end{array}$ & $\begin{array}{l}-249 \\
-249 \\
-249 \\
-249\end{array}$ & $\begin{array}{l}283,078 \\
282,803 \\
282,852 \\
283,165\end{array}$ & $\begin{array}{r}153 \\
-122 \\
-73 \\
240\end{array}$ \\
\hline Mean & & & & & & 282,925 & \pm 109 \\
\hline
\end{tabular}

Electrical equivalent of calorimeter system with $3,700.00 \mathrm{~g}$ water at $30^{\circ} \mathrm{C} .=15,720.0$ international joules per ${ }^{\circ} \mathrm{C}$.

\section{DATA OF OTHER INVESTIGATORS}

The heat of combustion of carbon monoxide was measured by Dulong ${ }^{15}$ in 1838, Andrews ${ }^{16}$ in 1848, Favre and Silbermann ${ }^{17}$ in 1852, Berthelot ${ }^{18}$ in 1878 and 1880, and Thomsen ${ }^{19}$ in 1880 . As before, only the results of Thomsen and of Berthelot are compared with those of the present investigation.

Thomsen reported the results of 10 experiments in which carbon monoxide was burned in oxygen at constant pressure. The results of Thomsen, corrected to international joules per mole at $30^{\circ} \mathrm{C}$. (presumably at $1 \mathrm{~atm}$. ), are given in Table 9 . The average value is $284,140 \pm 710$ international joules per mole. The assigned "error" includes an estimated error in calibration of 0.1 per cent and is calculated by equation (7).

$\mathrm{T}_{\mathrm{ABLE}}$ 9.-Results obtained by Thomsen on the combustion of carbon monoxide

\begin{tabular}{|c|c|c|}
\hline Experiment & $Q, 30^{\circ} \mathrm{C} . .1$ atm. & $\begin{array}{l}\text { Deviation } \\
\text { from mean }\end{array}$ \\
\hline 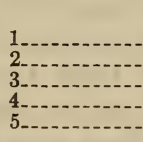 & $\begin{array}{c}\text { Int. joules/mole } \\
284,680 \\
284,120 \\
284,160 \\
282,580 \\
285,110\end{array}$ & $\begin{array}{r}580 \\
20 \\
60 \\
-1,520 \\
1,010\end{array}$ \\
\hline $\begin{array}{l}6-10.10 \\
7 \\
8 \\
9 \\
10\end{array}$ & $\begin{array}{l}283,980 \\
282,250 \\
283,930 \\
285,630 \\
281,590\end{array}$ & $\begin{array}{r}-120 \\
-1,850 \\
-170 \\
1,530 \\
490\end{array}$ \\
\hline Mean... & 284,140 & \pm 735 \\
\hline
\end{tabular}

Berthelot reported two values for constant pressure and two for constant volume. These data, corrected to international joules per mole at $30^{\circ} \mathrm{C}$., and $1 \mathrm{~atm}$., are given in Table 10 . The average value with its assigned "error" is $284,800 \pm 2,000$ international joules per mole.

13 Dulong, Comptes rendus, 7, p. 871; 1838.

16 Andrews, Phil. Mag., 32, p. 325; 1848.

17 Favre and Silbermann, Annales chim. phys., 34, p. 405; 1852

18 (a) Berthelot. Annales chim. phys., 13, p. 1; 1878; (b) 20, p. 255; 1880.

19 Thomsen, "Thermochemische Untersuchungen," II, p. 288, J. A. Barth, Leipzig, 1886. 


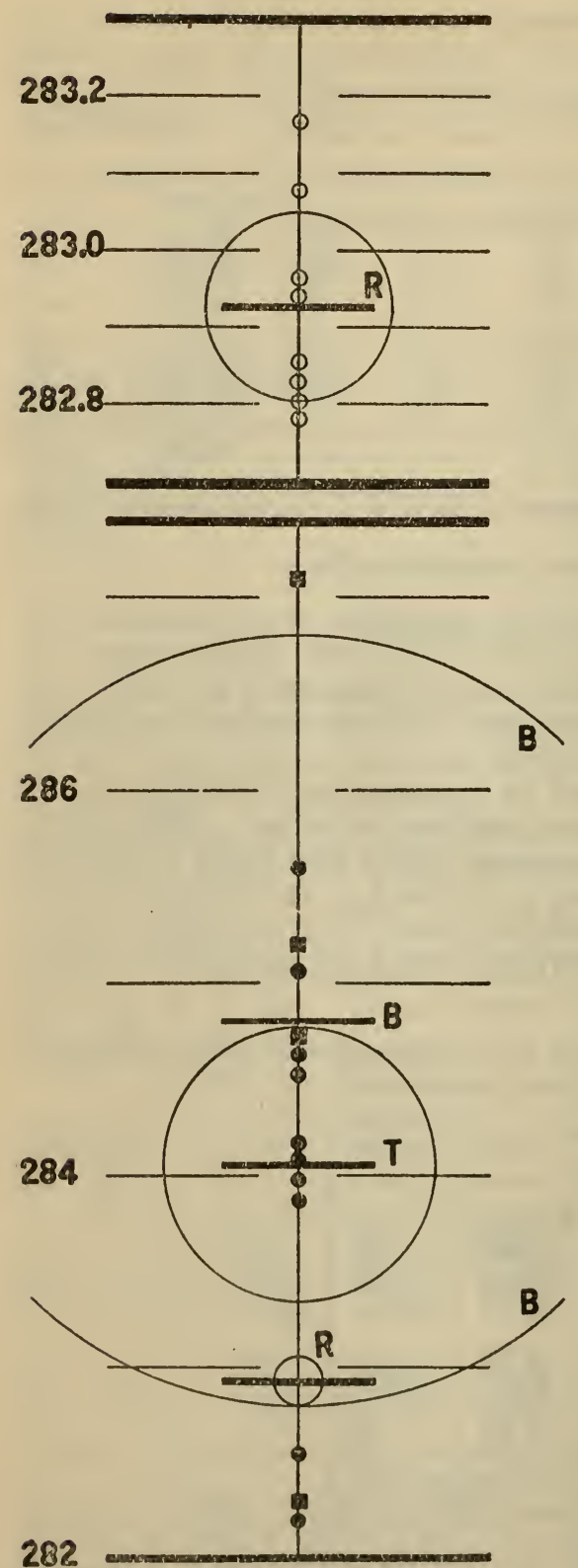

Figure 2.-Plot of the data on the heat of combustion of carbon monoxide

The ordinate scale gives the heat of combustion of carbon monoxide in international kilojoules per mole at $30^{\circ} \mathrm{C}$. and 1 atmosphere. The points designate the data of the various investigators:

Berthelot; 0 , 'Thomsen; O, Rossini.
TABLE 10.-Results obtained by Berthelot on the combustion of carbon monoxide

\begin{tabular}{|c|c|c|}
\hline Experiment & $Q, 30^{\circ} \mathrm{C} . .1 \mathrm{~atm}$. & $\begin{array}{l}\text { Deviation } \\
\text { from mean }\end{array}$ \\
\hline 1...... & $\begin{array}{c}\text { Int. joules/mole } \\
285,200 \\
284,700 \\
282,300 \\
287,100\end{array}$ & $\begin{array}{r}400 \\
-100 \\
-2,500 \\
2,300\end{array}$ \\
\hline Mean.. & 284,800 & $\pm 1,300$ \\
\hline
\end{tabular}

In Figure 2 are shown the individual values of Thomsen and of Berthelot, together with the data of the present investigation. The circles or arcs are drawn with radii equal to the assigned "errors." The upper part of Figure 2 shows a magnified view of that part of the lower scale in which fall the values of the present work.

\section{CONCLUSION}

On comparing the data of Thomsen and of Berthelot on the heats of combustion of methane and carbon monoxide with the data obtained in the present investigation, one finds that (1) the average values of Berthelot, plus or minus the assigned "errors," are in agreement with the values obtained in the present work and (2) that the average values of Thomsen, both for methane and carbon monoxide, have assigned to them "errors" which are too small (made so by the comparatively large number of observations) for agreement with the present data. This latter fact implies the existence of some systematic error in the measurements of Thomsen-of opposite sign in the two sets of data.

Conservative estimates of the uncertainty, from all causes, in the average values of the heats of combustion of methane and carbon monoxide as determined from the present data are, respectively, \pm 300 and \pm 120 joules per mole. 
From the data of the present investigation the heat of combustion of $\mathrm{CH}_{4}$ in $\mathrm{O}_{2}$ to form liquid $\mathrm{H}_{2} \mathrm{O}$ and gaseous $\mathrm{CO}_{2}$ according to equation (8) is $889,700 \pm 300$ international joules per mole at $30^{\circ} \mathrm{C}$. and a constant pressure of $1 \mathrm{~atm}$. For small changes in temperature and pressure this value changes, respectively, -93 joules per mole per degree increase in temperature and -6.7 joules per mole per $\mathrm{mm}$ increase in pressure.

From the present data the heat of combustion of $\mathrm{CO}$ in $\mathrm{O}_{2}$ to form $\mathrm{CO}_{2}$ according to equation (13) is $282,925 \pm 120$ international joules per mole at $30^{\circ} \mathrm{C}$. and a constant pressure of $1 \mathrm{~atm}$. For small changes, this value changes, respectively, +7 joules per mole per degree increase in temperature and -3.7 joules per mole per $\mathrm{mm}$ increase in pressure.

At $25^{\circ} \mathrm{C}$., and a constant pressure of 1 atm., these values in various units ${ }^{20}$ are, per mole:

\begin{tabular}{l|r|r|r}
\hline & International joules & Absolute joules & \multicolumn{1}{c}{ g-cal ${ }_{15}$} \\
\hline $\mathrm{CH}_{4} \ldots \ldots$ & $\begin{array}{r}890,160 \pm 300 \\
\mathrm{CO}\end{array}$ & $\begin{array}{r}890,520 \pm 300 \\
283,000 \pm 120\end{array}$ & $\begin{array}{r}212,790 \pm 70 \\
67,623 \pm 30\end{array}$ \\
\hline
\end{tabular}

These values are obtained by using the relations: 1 international. joule 1.0004 absolute joules, and $1 \mathrm{~g}$-cal ${ }_{15} \sim 4.185$ absolute joules.

\section{ACKNOWLEDGMENT}

This work is part of the program of thermochemical research which is being carried on at this bureau under the direction of E. W. Washburn, and the author is greatly indebted to him for his deep interest and helpful advice. The assistance of F. A. Smith in developing the flame technic is gratefully acknowledged.

Washington, October 11, 1930.

20 See footnote 1, p. 38. 